DOI : $10.24127 /$ biolova.v1i1.31

\begin{tabular}{l|lll}
\hline History Article & Received: February 2020 & Approved: February 2020 & Published: February 2020 \\
\hline
\end{tabular}

\title{
SINERGISME DAN ANTAGONISME BEBERAPA JENIS ISOLAT BAKTERI YANG DIKONSURSIUMKAN
}

\author{
M. Rustam Rifai ${ }^{1}$, Hening Widowati ${ }^{2}$, Agus Sutanto ${ }^{3}$ \\ ${ }^{1,2,3}$ Program Studi Pendidikan Biologi, Pascasarjana Universitas Muhammadiyah Metro \\ E-mail 1'rustamrifai96@gmail.com, ${ }^{2}$ hwummetro@gmail.com, ${ }^{3}$ sutanto11@gmail.com
}

\begin{abstract}
Abstrak: Konsorsium mikroorganisme merupakan gabungan populasi mikroba berupa komunitas yang memiliki hubungan kooperatif, komensal, dan mutualistik. Secara alami, bakteri dapat berkomunikasi satu sama lain. Sinergisme adalah dua spesies yang hidup bersama dan melakukan aktivitas yang tidak saling mengganggu, tetapi aktivitasnya bertentangan dengan urutan yang saling menguntungkan, sehingga hubungan kehidupan antar spesies disebut sinergisme. Antagonisme mengungkapkan hubungan yang ial. Satu spesies menghasilkan sesuatu yang meracuni spesies lainnya, sehingga pertumbuhan spesies terakhir sangat sulit. mendukung interaksi beberapa jenis mikroba yang saling menguntungkan / sinergis. Untuk melayani antibiosis / antagonisme dari beberapa jenis mikroba.
\end{abstract}

Kata Kunci: antagonisme, konsorsium, sinergisme

\begin{abstract}
The microorganism consortium is a mixture of microbial populations in the form of communities that have cooperative, commensal, and mutualistic relationships. Naturally bacteria are able to communicate with each other. Synergism is two species that live together and carry out activities that do not interfere with each other, but their activities are in conflict with a mutually beneficial sequence, so the living relationship between species is called synergism. Antagonism expresses an ial relationship. One species produces something that poisons the other species, so the growth of the latter species is very difficult. to support the interaction of several types of microbes that are mutually beneficial / synergistic. To serve antibiosis / antagonism of several types of microbes.
\end{abstract}

Keyword : antagonism, consortium, synergism

\section{How to Cite}

Rifa'i, M. Rustam, Hening Widowati, dan Agus Sutanto. 2020. Sinergisme dan Antagonisme Beberapa Jenis Isolat Bakteri yang Dikonsursiumkan . Biolova 1(1). 21-26 . 
Isolat Bakteri Indigen Limbah

Cair Nanas (LCN) yang telah didapatkan hasil 15 isolat yaitu $\mathrm{I}^{1} \mathrm{I}^{1}, \mathrm{I}^{2}$, $\mathrm{I}^{3}, \mathrm{I}^{4}, \mathrm{I}^{5}, \mathrm{I}^{6}, \mathrm{I}^{7}, \mathrm{I}^{8}, \mathrm{I}^{9}, \mathrm{I}^{10}, \mathrm{I}^{11}, \mathrm{I}^{12}, \mathrm{I}^{13}, \mathrm{I}^{14}$, $\mathrm{I}^{15}$, yang telah diisolasi dari PT Great Giant Pineapple (GGP) adalah isolat yang berpotensi sebagai pengurai limbah organik nanas dan memiliki kemampuan menghidrolisis amilum dan protein (Sutanto, 2011:152). Maka dari itu jika dikonsorsiumkan diasumsikan mempunyai potensi yang lebih bagus dibandingkan isolat yang tunggal.

Mikroorganisme yang berada di dalam tanah dapat berperan sebagai penyedia unsur hara bagi keberlangsungan hidup tanaman. Jumlah mikroorganisme tanah yang melimpah menggambarkan tingkat kesuburan tanah dan sifat tanah baik secara fisik maupun secara biologis. Berdasarkan pernyataan dari (Prayudyaningsih, dkk, 2015: 955) dapat dijelaskan bahwa tidak semua mikroorganisme yang diketahui memiliki sifat yang merugikan organisme lainnya, akan tetapi ada juga yang dapat menguntungkan. Bakteri tanah dapat menguntungkan bila kehadirannya berperan dalam siklus mineral, fiksasi nitrogen, perombakan residu pestisida, proses humifikasi, proses menyuburkan tanah. Salah satu bakteri yang dapat menyuburkan tanah adalah bakteri pelarut fosfat (BPF).

Mikroba tanah seperti bakteri Pseudomonas, Bacillus, Escherichia dan Xanthomonas, serta fungi Aspergillus, Penicillium, dan ulfuria dan golongan Aktinomesetes seperti Streptomyces mempunyai kemampuan melarutkan fosfat-anorganik tak larut dengan mensekresikan asam-asam organik (Saraswati, 2007: 39). Mengingat pentingnya mikroorganisme tanah khususnya bakteri di dalam tanah. Maka perlu dilakukan isolasi dan penentuan jumlah populasi bakteri yang terkandung di dalam tanah, serta menganalisis bakteri yang didapat dari setiap kedalaman yang berbeda. Sehingga mikroba atau bakteri tanah itu jika dikonsursiumkan diasumsikan juga memiliki potensi yang lebih bagus dibandingkan dari isolat yang tunggal di tanah tersebut.

Konsursium merupakan campuran populasi mikroba dalam bentuk komunitas yang mempunyai hubungan kooperatif, komensal, dan mutualitsik (Asri dan Zulaika, 2016: E 57). Konsorsium bakteri baik yang terbentuk secara alamiah maupun buatan memiliki kelebihan yaitu memiliki fungsi metabolisme yang saling melengkapi dalam suatu ekosistem.

Jika bakteri tanah mempunyai kemampuan menghambat bakteri lain atau pertumbuhan cendawan patogen maka dapat dikatakan bakteri tersebut bersifat antagonis, bakteri tersebut banyak mempunyai peranan sebagai agens pengendali biologi secara potensial dan dapat menekan penyakit layu yang disebabkan oleh patogen luar tanah. Bakteri antagonis merupakan agens antagonis yang berperan penting dalam rizosfer tanah. Bakteri agens antagonis dapat menekan cendawan ataupun bakteri lain yang antibioasis, bakteri tersebut berkompetisi dengan nutrisi atau parasitisme langsung.

Pada umumnya bakteri antagonis dalam aktifitas organisme yang satu dengan organisme yang lainnya, akan saling bersaing dalam memperebutkan tempat, udara, air, bahan makanan (nutrien). Jika bakteri tersebut tidak saling bersaing akan tetapi bakteri tersebut berinteraksi dan bersinergi, serta berbagi sumber nutrisi yang sama dan berperilaku kooperatif antar bakteri dalam habitatnya maka dapat dikatakan sinergisme.

Tujuan dari penulisan artikel ini adalah untuk mempelajari interaksi 
beberapa jenis mikroba yang saling menguntungkan/sinergis, serta untuk mempelajari antibiosis/antagonisme beberapa jenis mikroba.

\section{METODE}

Metode yang digunakan dalam artikel ini adalah studi dokumentasi mengkaji beberapa artikel yang berhubungan dengan sinergisme dan antagonisme beberapa jenis isolat bakteri yang dikonsursiumkan sebagai sumber belajar biologi.

\section{HASIL KAJIAN DAN PEMBAHASAN}

\section{Sinergisme Bakteri}

Kehidupan bakteri tidak hanya
dipengaruhi oleh faktor-faktor
lingkungan, akan tetapi juga
mempengaruhi keadaan lingkungan.
Bakteri dapat mengubah $\mathrm{pH}$ dari medium tempat ia hidup, perubahan ini disebut perubahan secara kimia. Adapun faktor-faktor lingkungan dapat dibagi atas faktor-faktor biotik dan faktor-faktor abiotik.Di mana, faktorfaktor biotik terdiri atas makhlukmakhluk hidup, yaitu mencakup adanya asosiasi atau kehidupan bersama antara mikroorganisme, dapat dalam bentuk simbiose, sinergisme, antibiose dan sintropisme.Sedangkan faktor-faktor abiotik terdiri atas faktor fisika (Hadioetomo, 1982).

Sinergisme adalah asosiasi atau hubungan hidup antara kedua spesies yang mana mengadakan kegiatan yang tidak saling menganggu satu sama lainnya. Akan tetapi kegiatan masingmasing justru merupakan urut-urutan yang saling menguntungkan. Sinergisme bakteri merupakan interaksi antara genus atau spesies bakteri yang satu dengan yang lainnya bersinergi, serta berbagi sumber nutrisi yang sama dalam media hidup yang sama.

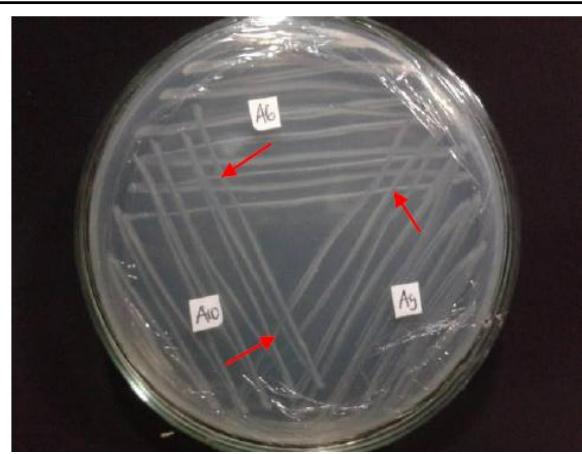

Gambar 1. Sinergisme antar Isolat A6 dengan A9, A9 dengan A10, dan A9 dengan A10

Sumber: Asri dan Zulaika (2016:E-58)

Berdasarkan uji sinergis antar isolat yang dikultur bersama pada media Azotobacter agar, semua isolat Azotobacter yaitu A1b, A3, A6, A9,dan A10 yang digunakan dapat bersinergi satu dengan yang lainnya. Dari hasil inkunasi selama 24 jam, masingmasing isoat yang bersinggungan tidak membentuk zona bening atau zona hambat (Gambar 1).

Adanya kompatibilitas atau sinergisme dari dua bakteri atau lebih yang diinokulasikan merupakan faktor yang sangat penting supaya bakteri tersebut dapat bekerjasama dengan baik. Bakteri dengan genus atau spesies yang sama dapat berinteraksi dan bersinergi, serta berbagi sumber nutrisi yang sama. Hal ini menujukkan perilaku kooperatid antar bakteri dalam suatu habitat dalam bentuk konsorsium. Suatu konsorsium akan menghasilkan produk yang dapat dimanfaatkan bersama, sehingga dapat saling mendukung pertumbuhan isolat tunggal dan lainnya (Asri dan Zulaika, 2016:E57).

Mekanisme sinergisme antar isolat dalam konsorsium masih belum diketahui dengan pasti, namun beberapa penelitian menduga disebabkan karena adanya beberapa faktor yang lain: (1) salah satu anggota genus mampu menyediakan satu atau lebih faktor nutrisi yang tidak dapat disintesis oleh anggota genus yang lain, 
(2) salah satu anggota genus yang tidak mampu mendegradasi bahan organik tertentu akan bergantung pada genus yang mampu menyediakan hasil degradasi bahan organik tersebut, (3) salah satu anggota genus melindungi anggota genus lain yang sensitif terhadap bahan organik yang bersifat toksis dengan cara memproduksi faktor proktektif yang spesifik maupun nonspesifik (Asri dan Zulaika, 2016:E58).

Untuk melihat bakteri yang bersifat sinergis dan antagonis yaitu dengan masing-masing isolat digoreskan secara bersinggungan satu sama lain dengan metode gores sehingga kedua antar isolat akan bertemu. Apabila isolat dikatakan kompatibel tidak terdapat zona hambat atau zona penghambatan sehingga disebut sinergis (Abdi, 2018).

\section{Antagonisme Bakteri}

Interaksi antar mikroorganisme yang menempati suatu habitat yang sama akanmemberikan pengaruh positif, saling menguntungkan dan pengaruh negatif, saling merugikan dan netral, tidak ada pengaruh yang berarti mikroorganisme harus berkompetisi dengan organisme lain dalam memperoleh nutrisi dari lingkungannya, sehingga dapat terus "lulus hidup" dan dapat berkembangbiak dengan sukses. Hubungan antara mikroorganisme dengan organisme lain yang saling menekan pertumbuhannya disebut antagonisme. Bentuk interaksi ini merupakan suatu hubungan asosial.

Biasanya Spesies yang satu menghasilkan suatu senyawa kimia yang dapat meracuni spesies lain yang menyebabkan pertumbuhan spesies lain tersebut terganggu. Biasanya bentuk interaksi ini muncul karena ada beberapa jenis miktororganisme yang menempati ruang dan waktu yang sama, sehingga mereka harus memperebutkan nutrisi untuk tetap dapat tumbuh dan berkembangbiak. Akhirnya dari interaksi semacam inimemberikan efek beberapa mikroorganisme tumbuh dengan optimal, sementara mikroorganisme lain tertekan pertumbuhannnya (Kusnadi, 2003).

$$
\text { Kompetisi menunjukkan }
$$
adanya interaksi negatif antar dua populasi mikroorganisme dimana kedua populasi tersebut akan terpengaruh kehidupan dan pertumbuhannya. Ketika salah satu populasi mikroorganisme memproduksi zat antimikroba untuk menghambat populasi lainnya maka interaksi antar kedua populasi tersebut disebut antagonisme.

Antagonisme adalah bilasatu pihak merugikan pihak lainnya, maka interaksi ini disebut antagonistik. Organisme semacam ini mungkin sangat berguna, oleh karena sering kali menghasilkan antibiotik ataupun substansi penghambat lainnya yang mampu menghambat pertumbuhan mikroorganisme lainnya. Contoh adalah antagonisme antara Staphylococcus aureus dan Pseudomonas auroginosa terhadap Aspergillus terreus. Pigmen dari Pseudomomnas mampu menghambat germinasi aspergillus, sedangkan Staphylococcus aureus menghasilkan bahan antifungal yang menyebabkan distorsi hifa disertai pembengkakan.

Meskipun organisme dari berbagai habitat menghasilkan antibiotik, namun mikroorganisme tanah merupakan penghasil utama metabolit ini. Satu organisme dapat menghasilkan 5-6 macam antibiotik, dan ini mungkin merupakan salah satu cara mikroorganisme mempertahankan dirinya di alam. Selain antibiotik fungsi juga mampu menghasilkan sianida yang bersifat toksik. Alga menghasilkan asam lemak yang bersifat antibakterial. Metabolit lainnya 
yang bersifat sebagai penghambat adalah metan, sulfda, dan senyawa sulfur lainnya. Banyak mikroorganisme tanah litik sehingga dinding sel dihancurkan dan protoplasmanya bersifat sebagai zat hara (Budiyanto 2004:193). Berikut zona hambat yang ditimbulkan oleh bakteri pada Gambar 2.

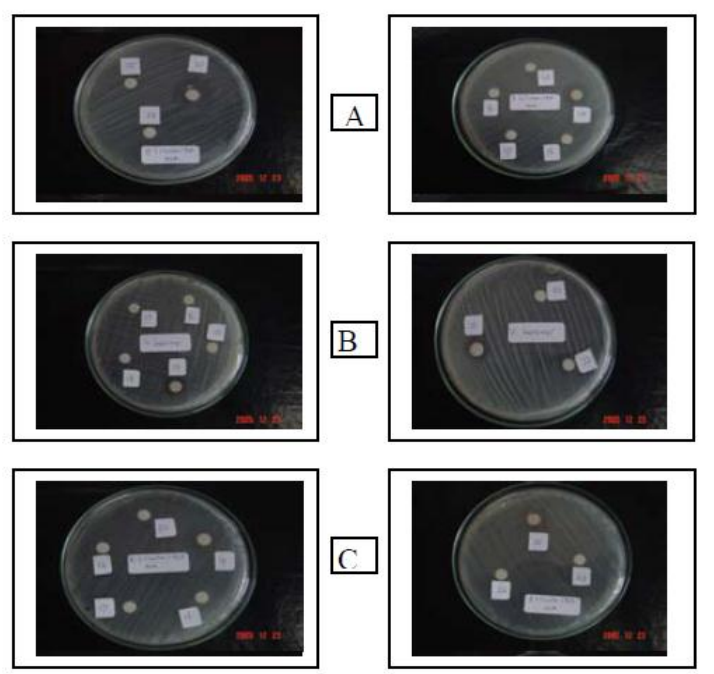

Gambar 2. Zona Hambatan yang Ditunjukkan oleh Bakteri Penghambat Sumber: Hatmanti, dkk (2009:84)

Apabila dikatakan tidak
kompatibel dan terdapat zona penghambatan pada daerah pertemuan kedua isolat tersebut maka dikatakan antagonisme. Zona jernih terbentuk karena bakteri yang tumbuh ternyata menghasilkan enzim, salah satu enzim yang dihasilkan enzim protease sehingga mampu menguraikan protein pada medium tumbuh. Misalnya bakteri proteolitik mengkonsumsi sumber karbon sederhana yang terkandung pada medium. Karbon dalam konsentrassi rendah dan kadar protein tinggi merangsang pembentukan enzim protease. Luas zona jernih atau bening yang terbentuk disekitar koloni menunjukkan perbedaan kemampuan bakteri tersebut dalam merombak nutrisi contohnya protein.
Terbentuknya zona hambat menandakan bahwa bakteri antagonis tersebut menghasilkan antibiotik. Antibiotik digolongkan sebagai metabolit sekunder yang dihasilkan oleh bakteri endofitik dan antagonis dalam jalur metabolisme dan oleh enzim yang tidak diperlukan untuk pertumbuhan dan pemelihran sel tumbuhan. Dengan adanya dugaan bahwa bakteri antagonis menghasilkan antibiotik maka mekanisme terpenting dari kerja antibiotik terhadap sel bakteri adalah menghambat sintesa protein dan asam nukleat oleh bakteri proteolitik, selain mekanisme tersebut aktivitas antibiotik juga meliputi perusakan dan penghambatan pembentukan dinding sel. Perubahan permeabilitas sel target dan penghambatan kerja enzim yang berperan dalam pertumbuhan bakteri (Gofar, dkk, 2014).

\section{KESIMPULAN}

Isolat antar jenis bakteri dikatakan kompatibel apabila tidak terdapat zona penghambatan pada daerah pertemuan kedua isolat maka dapat dikatakan sinergisme. Apabila dikatakan tidak kompatibel dan terdapat zona penghambatan pada daerah pertemuan antar isolat beberapa jenis bakteri tersebut maka dikatakan antagonisme.

\section{SARAN}

Penelitian mengenai sinergisme dan antagonisme agar dilakukan lebih mendalam mengenai beberapa jenis bakteri yang ada di alam dan belum pernah diuji kompatibilitas dan nonkompatibilitasnya khususnya pada bakteri indigen LCN dengan bakteri tanah.

DAFTAR RUJUKAN 
Asri, Anindya Citra dan Enny Zulaika. 2016. Sinergisme Antar Isolat Azotobacter yang Di konsorsiumkan. Jurnal Sains dan Seni ITS. Vol.5, No.2, (2016) 2337-3520 (2301928X Print).

Abdi, Popo Mogana. 2018. Sinergisme Bakteri Selulolitik Berbasis Limbah Jagung sebagai Bioaktivator Pakan Berserat. Skripsi diterbitkan. Sumatera Utara: Program Studi Peternakan, Fakultas Pertanian. Universitas Sumatera Utara.

Budiyanto, Agus Krisno. 2004. Mikrobiologi Terapan. Malang: Universitas Muhammadiyah Malang.

Gofar, Nuni; Hary Widjajanti, dan Angga Prasetya Mulya. 2014. Eksplorasi Bakteri Antagonis Asal Jaringan dan Rizosfer Tanaman Karet untuk Menekan Pertumbuhan Bakteri Proteolitik pada Bahan Olahan Karet (BOKAR). Jurnal Tanah Lingkungan. ISSN 14107333.

Hadioetomo, Sri Ratna. 1982. Mikrobiologi Dasar dalam Praktek. Jakarta: Gramedia.

Hatmanti, Ariani; Ruyitno Nuchsin; dan Julinasari Dewi. 2009. Screening Bakteri Penghambat untuk Bakteri Penyebab Penyakit pada Budidaya Ikan Kerapu dari Perairan Banten dan Lampung. Makara, Sains. Vol.13., No. 1, April 2009: 81-86.

Kusnadi; Yanti Hamdiyati; Ani Fitriani. 2003. Mikrobiologi. Bandung: FMIPA Universitas Pendidikan Indonesia.

Saraswati, Rasti; Edi Husen; RDM Simanungkalit. 2007. Metode
Analisis Biologi Tanah. Bogor: Balai Besar Penelitian dan Pengembangan Sumber daya Lahan Pertanian.

Sutanto, Agus. 2011. Degradasi Bahan Organik Limbah Cair Nanas oleh Bakteri Indigen. ElHayah. Vol.1, No.4 Maret 2011. Page 151 of 156.

Prayudyaningsih, Retno, Nursyamsi, Ramdana Sari. 2015. Mikroorganisme Tanah Bermanfaat pada Rhizosfer Tanaman Umbi di Bawah Tegakan Hutan Rakyat Sulawesi Selatan. Prosiding Seminar Nasional Masy Biodiv Indon. Volume 1, Nomor 4, Juli 2015. Halaman: 954-959. ISSN: 2407-8050. 